\title{
Cyber Technologies in Organized Crime Investigations
}

\author{
MILICA D. ĐEKIĆ, Subotica
}

Review paper

$U D C:$ 343.985:004.6

DOI: 10.5937/tehnika2102254D

Today's human population got dependable on cyber technologies bringing us a lot of benefits as well as nightmares. Some studies suggest that there are several billions internet connections worldwide and they are not only in hands of the Legal Forces, but rather with the criminals, terrorists and the other harmful actors. So, as we all are dependable on new technologies - our opponents are at the same position as well. Through this research article, we plan to talk about the challenges of the organized crime to modern societies, their impacts to world's population, culture and economy and finally provide some correlations between the cyberspace and the criminal environment suggesting how some heavy cases in criminology could get investigated using computers, web and mobile technologies.

Key words: cyber security, criminology, intelligence, case, policing

\section{INTRODUCTION}

In a practice, the organized crime would include the drug-related crimes, prostitution, pornography, some sex-related crimes, human trafficking, corruption, money laundering and the rest of the heavy cases including the murders. As the all segments of a human's society got dependable on modern technologies, the criminal environment is not an exemption as well. Many heavy cases could get resolved or even prevented using the good intelligence techniques through the investigative processes. For instance, the cyber would cover on computers, web and mobile devices - so it's not hard to guess how the advantages of these network-based systems could be used for the information as well as the evidence gathering. Also, what could get recommended here is the usage of the technological solutions such as telecommunication or satellite systems which should get included for an accurate gathering of the findings.

Many organized crime offences would rely on the emerging technologies such as mobile phones, the web environment including the Deep Web gadgets for a confidential communication, some computer applications for an information exchange, many recording equipments and so on $[14,16]$. Like everyone else, the Subotica

Author's address: Milica Đekić, Vase Pelagića 39,

e-mail: milicadjekic82@gmail.com

Paper received: 08.01.2021.

Paper accepted: 28.01.2021. criminals would take advantage of this modern era. It's getting clear that using those cyberspace-related benefits; the organized crime groups would leave a trace about their activities, communications and information sharing.

These would be so useful for the defense services for the reason of a quite convenient findings gathering, tracking of the criminal communication and planning the next case's moves as well as the arrest.

At the beginning of the case, the authorities would get some information - probably some findings from the crime scene, so they would begin their search and some sort of the linkage attempting to correlate what they already know with such an occurrence. So often, the Police may identify the completely new criminal organization and find some details about their links with the many others.

The investigation is a discrete process which would get led with the highest level of the confidentiality $[12,15]$. Practically, that's the ultimate requirement, but the experience suggests that the heavy cases may break into the investigation and try to disturb its flow. The modern security-intelligence community would deal with such a finding and use the cyber forensics to trace the route of the criminals or even the terrorists which would attempt to spy on the Defense Forces.

The final aim of the investigation is to gain as many findings and evidence as it can and to make an arrest of all malicious actors involved into the heavy crimes. 


\section{THE ORGANIZED CRIME DEPENDS ON NEW TECHNOLOGIES}

During the history, the crime would pass through many phases - it would mostly be correlated with the physical domain and use the weapons suitable to one period of the human's development for committing the heavy offences, but today it would rapidly move to a cyberspace. At the moment, we are not fully with the cyber age talking about the crime. This stage could get described as a transition from the physical to cyber epoch regarding the criminal offences. The current tendency suggests that very soon the banks would not get robbed from the inside using the guns and wellorganized logistics, but rather from the outside using the remote technologies. So, we are obviously moving from a physically-oriented crime era to the cyber age of the crime offences which means this new time with the criminology requires the new skills and expertise by the defense staff being capable to respond to the challenges of this new epoch.
Through our theoretical research, we would obtain some useful information on how the organized crime works and how it's dependable on a new technology. Using these findings, we would create the Table 1 trying to discuss how the usage of cyber technologies may differ depending on a crime type.

These results are only the estimated data which could be used to give some sort of indicators and insights on how it goes in a practice. As it's known, the drug-related crimes are the most serious criminal offences due to the big budget the criminal organization dealing with $[12,14,16]$.

This sort of the criminal business may be the serious threat to the Legal System as well as the Defense Forces, because through their funds - they may sponsor the very competitive security's threats which would go against everything legal, fight for their drug lords and try to make a punch to many countries and their governments.

Table 1. The estimated usage of cyber technologies within basic crime types

The usage of cyber technologies

\begin{tabular}{|l|l|l|l|l|l|}
\hline Crime types & Very low & Low & Moderate & High & Very high \\
\hline Drug-related & & & & & $\mathbf{X}$ \\
\hline Sex-related & & & $\mathbf{X}$ & & \\
\hline Human trafficking & & & & $\mathbf{X}$ & \\
\hline Murder & & & $\mathbf{X}$ & & \\
\hline Weaponry case & & $\mathbf{X}$ & & & \\
\hline
\end{tabular}

Being the part of the criminal environment, those groups would not pay the tax to their states making the nation's economy weaker. Also, they would recruit many young and capable people which could be the good Labor Force to their countries and which lives would get destroyed through the criminal businesses. The experience from the Balkans suggests that the entire generation range got lost to their society through this sort of illegal activities, which would make this region so concerning to the rest of the world. In addition, the drug-related crimes would rely on skillful hackers which would gather the information to them in order to support those criminals protect their interests within their narcotics-distribution territory. The tendency indicates that the drug bosses could so easily try to run the entire cyber warfare against everyone trying to threaten them. The drug-related crimes are well-known by its brutality and the Defense Forces need the strong and highly capable people to investigate and resolve these cases.

The sex-related crimes may include the rape, prostitution, pedophilia, pornography and much more [3]. These sorts of the criminal offences are moderately correlated with the usage of cyber technologies.
Sometimes the gangs would use the cybercriminals with some hacking skills to track the victims and obtain more information about them through the web's or physical stalking. Many of these cases just like the human trafficking may get in a correlation with the kidnapping scenarios being carefully coordinated using cyber tracking techniques [14]. The victims of the human trafficking normally got no human rights and they are simply forced to get physically, sexually or mentally exploited.

Finally, the heavy cases such as the homicides and weapon-related crimes may be moderately to lowly correlate with the application of the emerging technologies. The weaponry cases may include the firearm smuggling and use. It's obvious that this sort of the criminal offences needs the good network's work, so some sort of the communications capacities may be invoked correlating these with the cyber technologies as well. The hacker's skills are also welcome within such an organization for the reason of obtaining the fake documents for the unaffected crossing of the boarders. Many of the organized crime groups would have the international members making such an organization being with the transnational character. This 
sort of the scenario would demand the international collaboration of the local authorities as well as the global intelligence community.

\section{THE GOOD EXAMPLE OF THE CASE INVESTIGATION}

When the crime occurs, the Police usually arrive at the crime scene when the criminals are not there. What they can do at that stage is to carefully examine the crime scene and start the search for the suspects. All the Police's tasks are conducted discretely and the authorities would not share lots of details which the public trying to protect the interests of the case. Sometimes the Police may seek the public assistance, but they would never release a plenty of information, because the criminals could get how the case progresses [1,2]. After the first interviewing of the witnesses, the Police would get some initial information about what happened with the crime scene and they may keep with the investigation using the advantages of the current technology. It's important to mention that the interviewing of the witnesses or the persons involved in the case providing some findings to the investigation is highly modernized and may occur at any place convenient to the source of information $[14$, $16]$.

The first assumption the authorities could make is that someone close to the crime scene could be in a contact with the suspects before, so they may try to search through those contacts. Also, the criminals would do a lot of tracking - either physical or cyber carefully planning to make a move about their target. All these evidence would get available through the cyberspace and obtainable through the well-coordinated forensic investigation. Finally, the investigators may assume that the criminals would get present at the crime scene with their mobile phones or some other electronic devices, so they may try to re-construct the event using the details available through the telecommunication network providers. This sort of the search may give them the findings about the criminal actor's mobile device number as well as his phone route with the surrounding space. If the cell phone is still active, the suspects could be located and all their contacts could get identified and investigated.

Once the Police obtain the information where the gang's whereby could be, they can try to investigate that place from the outside and attempt to get as many information as they could to go deep with the case and finally make some arrests. The arrest means that the criminals would get the custody and the opportunity to prove through the court's process if they are guilty or not. It takes a lot of time and effort before someone gets his final penalty for his crimes [14]. However, if the Police deal with some information about the gang's location, they would try to gather all the useful findings monitoring the phone lines, computer's and the other devices microphones, the Internet and utility connections and carefully recording such a place from the outside using satellite systems, diverse camera equipments or even sending some of their staff to try to obtain the information and deal with the risky task such as the insider's one. The practice shows that some people from the criminal environment are willing to do a negotiation with the authorities and share their findings with the Legal Forces taking the role of the informant within the case. Basically, the informant may be legally clean person, but the best findings about the crime come from the persons involved into some criminal offences.

The modern investigations would deal with the intelligence-led approach $[14,16]$. This would mean that some well-planned inputs would get sent to the suspects or some investigation's members in order to obtain some helpful findings to the case. The inputs could get make through the e-mail, phone, computer, social media or any other communications. Once you send some encouragement to the investigation's target, you would get some response which would by many cases be the useful information getting analyzed and used for producing some intelligence.

The analysis would include a lot of statistical work and a plenty of critical thinking and careful decision making conducted to prepare the next move with the investigation. The investigative process would include the constant flow of the new findings which must be processed and used to send some inputs through trying to direct the case on the desired track. In a practice, the criminals may try to affect the investigation attempting to influence its final score, so it's recommended to the authorities conducting the investigative process to take the case under a control as good as they could.

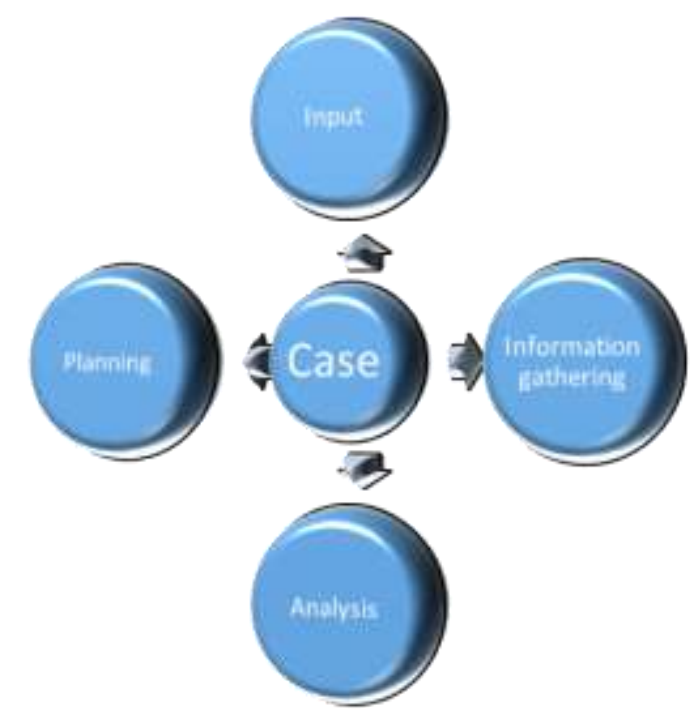

Figure 1 - The intelligence-led investigation 
As it's suggested through the Figure 1, the intelligence-led case may cover the four steps which are (1) providing the inputs to the investigation, (2) gathering such an obtained information, (3) doing some skillful analysis and finally (4) make some strategic planning about the next move with the case. Some investigations may take several weeks or months, while the organized crime cases may last many years. Such a case would require well-trained people capable to learn quickly and follow the new trends within security and technology. As we mentioned before, this era is correlated with lots of technological advancments and the defense staff must be able to cope with those. We would also suggest that this period with the security may be recognized as a transition between the fully physical ages of the crime into a completely technological time to the criminals. Whichever situation we got within the human's society, the defense is supposed to go ahead of the malicious actors in order to protect its people from harm. The modern security is not about having some Defense Forces established it's rather about putting a lot of effort every single day to make things get secured.

\section{THE FORENSIC EXAMINATIONS OF THE COLLECTED EVIDENCE}

As an example of the criminal offences, we would try to deal with the drug-related crimes and attempt to explain how such an investigation would go in a forensic manner. Even through the case, the Police may collect a lot of evidence which could lead to an arrest and lately gets used during the court's process to prove someone's status by the crime's law. The drugrelated offences would include dealing with the narcotics which would require the skillful forensic detectives and many laboratory examinations which should confirm the chemical background of the psychoactive substance. In case of the drug smuggling, when the raid gets in a possession of the several tones of the drug, some sample of the collected transportation would get sent to a chemical analysis $[2,14,16]$. The drug parcels are usually discovered through the careful search of some transpiration device as well as the usage of welltrained animals that can smell the drug. The drugrelated crimes with the Balkan's area are commonly correlated with the money laundering activities indicating that the drug lord's intent to insert his money obtained through the heavy crimes into the legal flows.

Today's organized crime groups would make their business deals through the Internet, phone lines, the classical correspondence and sometimes in a person. All these mean that they would leave lots of evidence about what they do, so the defense needs to know how to collect and analyze them. So often the heavy drug lords would get the confidence to spy on the authorities and even the world-class intelligence services in order to obtain the confidential information about the their own cases. These would get possible using the skillful hackers and the other sophisticated advantages of the modern time. The Balkan's gangs are well-known for their habits to consult the persons with the physic skills being the part of their cultural identity. The expert's community with the field of interests into the paranormal phenomena may understand how serious threat to the security could be a well-trained agent used for the mind-to-mind transfer of the information, findings and psychic knowledge $[14,16]$. Through this article, we would not discuss further such a case for the reason of the existing many specialized investigations dealing with the consciousness research concerns.

Next, the recent findings would suggest that the organized crime groups leave lots of evidence within a cyberspace. They would frequently use the Dark Internet to maintain the communications; exchange the information or order some good or service through this sort of the web carefully designed to offer the sort of secure communications [16]. The most commonly used Deep Web's tool is a TOR which would appear as so convenient for making the accounts, the information exchange and organizing new crimes. The experience would suggest that this communication even being officially anonymous - it can be monitored through the professional security tools. Also, the rest of the computer's and Internet's activities could get monitored remotely through the security equipment which would not get dependable on the web's connectivity. It's interesting to mention that the range to the workstation would play the key role, so - in other words, it's important to stay close enough to the monitored device in order to throw the signal from the equipping antenna and catch the response back. The good evidence about the criminal offences is not only the recorded communications between the gang's members or some other sort of the records including video materials, photos or audio findings, but rather here could be mentioned the monetary flows being discovered through the banking activities and the money transfer within some financial organization.

In addition, it's highly recommended to the majority of defense staff dealing with the cyber forensic investigation to stay updated about new trends and follow the new offers on the web regarding some investigative software solutions. The organized crime groups with the good budget may get overconfident and hire the team of the professional hackers which would break directly into a communication of the Defense Forces or even make a breach to their workstations and networks $[17,18]$. The good suggestion would be that the security digital systems should get the periodical checkups or some sort of forensic 
investigation in order to discover the breach, catch the offenders and prevent the systems from the new crimes. In a practice, the effective investigation needs the highly capable and skillful security staff to deal with the case. This is so important, because every single day longer with the case would cost the government's budget more. So, it's advised to think how to be the time as well as the cost effective dealing with the policing tasks.

\section{THE WAYS TO EFFECTIVELY RESOLVE THE CASE}

The crime prevention is something about every competitive Police Department thinks about. The wellknown way to prevent something happens is to get some areas covered with the people, equipment or patrolling vehicles. In terms of urban area, it's not that bad idea at all to get the Police staff inserted into the risky parts of the community even in the uniforms - or better with the civilian appearance. Those professionals should get equipped with the microphones or the network scanners and sent there to report if anything suspicious occurs $[14,16]$. Also, the good idea is to cover some suburbs with the patrolling vehicle in order to protect the population from the local gangs. In addition, the Police are supposed to respond to every phone call, but sometimes they need to decide if it's necessary to come or not due to the plenty phone calls may be fake or unreasonable. Which decision would get made depends on the experience of the call center staff. In any case, the Police staff must be very capable and highly skillful because of many tasks they need to resolve during their serving career. It's recommended to think how to proactively prevent the crime using some of the intelligence-led techniques. For instance, if the Police Force deals with some concerning area within the community - it should think how to make criminals leave some trace without committing the real crime. Once the criminal group got identified, it's not that hard to send its members some inputs as suggested with the chapter above. The good option is to gather the information about the planned crime and to put the Police officers around the potential crime scene to prevent that crime occurs at the certain period of the day.

The effectiveness of the case investigation may be directly correlated with the skillfulness of the defense staff dealing with that. It's highly recommended to the security professionals to try to leverage their capacities through the continuous trainings, educations and another learning using the different sorts of online recourses $[4,5,6]$. For instance, today's supreme requirement within every employer is a certain level of the IT skills. The security seeks more. It requires from their staff to get familiar and so often expertise the cyber defense. As it's known, the billions of people worldwide use the Internet and it's clear that the majority of the global community does its activities online. Practically, if the security is about the society's control and it could get diagnosed that big shift from the physical to cyber domain - it's getting clear that the current defense already needs to think how to make „The Law and Order" for that aspect of the human's society. The effectively and accurately concluded investigation is the imperative of the modern defense. It's encouraging to do the time effective investigation, because it would cost less the budget of the country's government. The recent findings and gained expertise within the defense community suggest that the future cases could be less time consuming applying the wellcreated and optimally delivered trainings to the security professionals.

The good organized continuous education to the security staff would offer them to gain the skills to deal with some tasks as well as better insight what about their profession is. The skills could get better developed through lots of practice, so at the final stage - we could get well-trained and extremely quick professional which would get capable to resolve the complicated tasks qualitatively and effectively. This like everything else would protect the national interests as well as the finances, so we could suggest this option to the governmental sector. The defense would definitely work for the country's interests - preventing the crime and protecting the nation gets robbed by the organized crime groups, but if it's time effective and less costing - it would certainly get accepted by everyone. The investments in terms of provided trainings, facilities and equipments would get promptly returnable to their investors. As the economy would suggest, the best results with some business are getting obtained when the business invests some funds into a new technology and make its employees trained to use it. For every business this would mean the rising productivity curve for some period of time. Finally, the security is just the business like anything else - right?

\section{DISCUSSIONS}

Through this article, we would try to discuss some perspectives of the organized crime as well as the methods suggesting how to investigate, resolve and conclude those cases. The organized crime so frequently has the international character and it's organized like a network-based business offering its strong hierarchy. The authorities dealing with this sort of offences must get networked as well and so often play as a team. The criminals always insist to get some sort of the advantage, but the Security Forces are supposed to suspend them and put their actions into a place. Many criminal organizations are recognized by its 
brutality and the security requires the capable staff to protect their people as well as the international community from such a criminal activity. The general recommendation would suggest the security should be about the maintaining the risk at an acceptable level which includes putting lots of effort and time on a regular basis to make things work. The defense is a serious business and needs that kind of staff approaching the life as well as the work using the seriously responsible manner. The final advice would include that every competitive nation should understand the importance of the defense through the skillfully prepared awareness programs and do the good investments into that branch of the human's activity [1-46].

\section{CONCLUSIONS}

This research contribution would provide a comprehensive insight into the challenges of the organized crime and the ways how to investigate such a case. We would deal with the plenty of examples and practical experiences trying to illustrate how the realcase scenarios work.

\section{ACKNOWLEDGEMENTS}

Milica is deeply thankful to her good family for all their love, care and support through her life.

\section{REFERENCES}

[1] Behl A, Behl K, An Analysis of Cloud Computing Security Issues, In Proc. 2012 World Congress on Information and Communication Technologies, IEEE, Trivandrum, India, pp. 109-114, 30 Oct.-2 Nov. 2012.

[2] Charney S, Rethinking the Cyber Threat: A Framework and Path Forward, Microsoft Corp., 2009.

[3] Delgado A, Ensuring our Children's Safety While Connected, The US Air Force Central Command, 2015, [Internet], The WEB source: http://www.afcent.af.mil/Units/379thAirExpeditionaryWing/Ne ws/Display/tabid/298/Article/622136/ensuring-ourchildrens-safety-while-connected.aspx

[4] Booz Allen Hamilton, Cyber Operations Maturity Framework: A Model for Collaborative, Dynamic Cybersecurity, 2011.

[5] Jason H, Cloud Attack: Unsharing Your Business in The Cloud, BrightTALK, 2015.

[6] Khalil I. M, Khreishah A, Bouktif S, Ahmad A, Security Concerns in Cloud Computing, In Proc. 10th International Conference on Information Technology: New Generations, pp. 411-416, Las Vegas, NV, USA, 2013.
[7] Lenkala S. R, Shetty S, Xiong K, Security Risk Assessment of Cloud Carrier, In Proc. 13th IEEE/ACM International Symposium on Cluster, Cloud, and Grid Computing, Delft, Netherlands, pp. 442-449, 2013.

[8] Liu W, Research on cloud computing security problem and strategy, In Proc. 2nd International Conference on Consumer Electronics, Communications and Networks (CECNet), Yichang, China, pp. 12161219, 2012.

[9] Mateski M, Trevino C. M, Veitch CK, Michalski J, Harris J. M, Maruoka S, Frye J, Cyber Threat Metrics, Technical Report, Sandia National Laboratories, United States, 2012.

[10]Meghanathan N, Review of Access Control Models for Cloud Computing, Computer Science \& Information Technology (CS \& IT), 2013.

[11]Hoang Ngo H, Wu X, Dung Le P, Wilson C, Srinivasan B, Dynamic Key Cryptography and Applications, International Journal of Network Security, Vol.10, No.3, pp.161-174, May 2010.

[12]Omari A, Al-Kasasbeh B, Al-Qutaish R, Muhairat M. DEA-RTA: A Dynamic Encryption Algorithm for the Real-Time Applications, International journal of computers, Vol. 3, Issue 1, pp. 191-199, 2009.

[13]Payne S. C, A Guide to Security Metrics, SANS Institute, 2007.

[14]Peterson M, Intelligence-Led Policing: The New Intelligence Architecture, Bureau of Justice Assistance, 2005.

[15]Schulze H, Insider Threat Report, Crowd Research Partners, 2015.

[16]The Europol, The Internet Organized Crime Threat Assessment, European Police Office, 2014.

[17]White G. B, The Community Cyber Security Maturity Model, In Proc. 40th Hawaii International Conference on System Sciences, Academic Press, 2007.

[18]Zhang N, Liu D, Zhang Y, A Research on Cloud Computing Security, In Proc. 2013 International Conference on Information Technology and Applications, pp. 370-373, 2013.

[19]Mester G, Cloud Robotics Model, Interdisciplinary Description of Complex Systems, Vol. 13, No. 1, ISSN 1334-4684, DOI:10.7906/indecs.13.1.1., pp. 1-8, 2015.

[20]Mester G, Rodic A, Simulation of Quad-rotor Flight Dynamics for the Analysis of Control, Spatial Navi- 
gation and Obstacle Avoidance, In Proc. 3rd International Workshop on Advanced Computational Intelligence and Intelligent Informatics (IWACIII 2013), Shanghai, China, ISSN: 2185-758X, pp. 1-4, October 18 to $21,2013$.

[21]Mester G, Massive Open Online Courses in Education of Robotics, Interdisciplinary Description of Complex Systems, Croatien Interdisciplinary Society, Vol. 14, No. 2, ISSN 1334-4684, DOI: 10.7906 /indecs. 14.2.7, pp. 182-187, 2016.

[22]Mester G. Merenje rezultata naučnog rada, TehnikaMašinstvo, Belgrade, Serbia, Vol. 64, No. 3, ISSN 0040-2176, pp. 445-454, 2015.

[23]Mester G. Academic Ranking of World Universities 2009/2010, Ipsi Journal, Transactions on Internet Research, TIR, Belgrade, ISSN 1820 - 4503, Vol. 7, No. 1, pp. 44-47, 2011.

[24]Gyula Mester G, 23 - 26. 02. 2015, Novi trendovi naučne metrike, In Proc. XXI Skup Trendovi Razvoja: ,,Univerzitet u Promenama...”, TREND 2015, Zlatibor, Serbia, ISBN 978-86-7892-680-8, DOI: 10.13140/RG.2.1.1754.2486, paper No. UP 1-3, pp. 23-30, 23 - 26. 02. 2015.

[25]Rodic A, Mester G. Control of a Quadrotor Flight, In Proc. Conference: ICIST Conference, Kopaonik, Serbia, ISBN: 978-86-85525-12-4, pp. 61-66, 0306.03.2013.

[26]Mester G, Modeling of Autonomous Hexa-Rotor Microcopter, In Proc. IIIrd International Conference and Workshop Mechatronics in Practice and Education, MechEdu 2015, Subotica, Serbia, ISBN 97886-918815-0-4, pp. 88-91, May 14-16, 2015.

[27]Mester G, Rodic A, Navigation of an Autonomous Outdoor Quadrotor Helicopter, In Proc. 2nd International Conference on Internet Society Technologie and Management ICIST, Kopaonik, Serbia, ISBN: 978-86-85525-10-0, pp. 259-262, 01-03.03.2012.

[28]Mester G, Obstacle - Slope Avoidance and Velocity Control of Wheeled Mobile Robots Using Fuzzy Reasoning, In Proc. IEEE 13th International Conference on Intelligent Engineering Systems, INES 2009, Barbados, ISBN: 978-1-4244-4113-6, DOI: 10.1109INES.2009.4924770, pp. 245-249, April 16-18, 2009.

[29]Mester G, Backstepping Control for Hexa-Rotor Microcopter, Acta Technica Corviniensis - Bulletin of Engineering, Tome VIII, Fascicule 3, ISSN 20673809, pp. 121-125, July - September, 2015.

[30]Mester G, New Trends in Scientometrics, In Proc. 33nd International Conference Science in Practice -
SIP 2015, Schweinfurt, Germany, pp. 22-27, 0708.05.2015.

[31]Kasac J, Milic V, Stepanic J, Mester G, A Computational Approach to Parameter Identification of Spatially Distributed Nonlinear Systems with Unknown Initial Conditions, In Proc. IEEE Symposium on Robotic Intelligence in Informationally Structured Space RiiSS (2014), Orlando, Florida, USA. DOI:10.1109/ IISS.2014.7009170, ISBN: 9781479944637, p. 154, Vol. 1, pp. 55-61, 9-12 December 2014.

[32]Mester G, Metode naučne metrike i rangiranja naučnih rezultata, In Proc. 57th ETRAN Conference, Zlatibor, Serbia, pp. RO3.5.1-3, 3-6. June 2013.

[33]Rodic A, Mester G. Ambientally Aware Bi-Functional Ground-Aerial Robot-Sensor Networked System for Remote Environmental Surveillance and Monitoring Tasks, In Proc. 55th ETRAN Conference, Section Robotics, Society for Electronics, Telecommunications, Computers, Automatic Control and Nuclear Engineering, Banja Vrućica, Bosnia and Herzegovina, Vol. RO2.5, ISBN 978-86-80509-66-2, pp 1-4, June 6-9, 2011.

[34]Đekić M. D, Kako sačuvati kontinuitet u poslovanju uprkos cyber incidentima, Tehnika, Vol. 70, No. 2, pp. 346-349, 2015.

[35]Đekić M. D, Cyber procedure za poslovno okruženje u Srbiji, Tehnika, Vol. 71, pp. 471-474, 2016.

[36]Đekić M. D, The Cloud's Computing Security, Tehnika, Vol. 73, No. 2, pp. 300-304, 2018.

[37]Đekić M. D, The Internet of Things Security, Tehnika, Vol. 72, No. 2, pp. 309-312, 2017.

[38]Đekić M. D, The Commerce Crime and Ways of Conducting a Financial Security, Tehnika, Vol. 71, No. 5, pp. 782-786, 2016.

[39]Đekić M. D, Cyber Procedures for a Business Environment in Serbia, Tehnika, Vol. 71, No. 3, pp. 471474, 2016

[40]Đekić M. D, The Internet of Things Cybersecurity Standardization, Tehnika, Vol. 74, No. 4, pp. 603607, 2019.

[41]Đekić M. D, The Application of Marketing for Small and Medium-sized Enterprises Competiveness Rise in the Republic of Serbia, Tehnika, Vol. 72, No. 4, pp. 587-590, 2017.

[42]Đekić M. D, A Smart Configuration of Computer as a Prevention from Hacking and Cyber Espionage, Tehnika, Vol. 71, No. 5, pp. 761-764, 2016.

[43]Đekić M. D, How to Create Training for the IT Industry's Staffs? Tehnika, Vol. 71, No. 4, pp. 644647, 2016. 
[44]Đekić M. D, How to Maintain a Business Continuity Despite Cyber Incidents? Tehnika, Vol. 70, No. 2, pp. 346-349, 2015

[45]Đekić M. D, The Use of Video Detection as a Function of Traffic Safety, Tehnika, Vol. 66, No. 3, pp.471-475, 2011.
[46]Đekić M. D, How a modern business could respond to the Phishing Attack Challenges, Tehnika, Vol. 72, No.3, pp. 455-459, 2017.

\section{REZIME}

\section{NOVE TEHNOLOGIJE U ISTRAGAMA ORGANIZOVANOG KRIMINALA}

Današnja ljudska populacija je postala zavisna od novih tehnologija koje imaju kako prednosti tako $i$ nedostatke. Neke studije sugerišu da postoji nekoliko milijardi internet konekcija širom sveta i one nisu samo u rukama legalnih snaga već i kriminalaca i terorista. Dakle, kako smo svi mi zavisni od visokih tehnologija - naši neprijatelji su u istom položaju, takođe. Kroz ovaj istraživački članak, planiramo da pričamo o izazovima organizovanog kriminala u savremenim društvima, njihovom uticaju na svetsku populaciju, kulturu i ekonomiju i da konačno, obezbedimo neke korelacije između visokotehnološkog prostora I kriminalnog miljea sugerišući kako neki teški slučajevi u kriminologiju mogu da budu istraženi koristeći računare, web i mobilne tehnologije.

Ključne reči: visokotehnološka bezbednost, kriminologija, saznanje, slučaj, policija 